\title{
LANGUAGE AS A SIGN OF POWER IN THE HANDMAID'S TALE
}

\author{
Mahshid Namjoo
}

\begin{abstract}
A language which seems to be an ordinary tool of communication can have a very critical and interesting role to shape the individuality and mentality of a person. The Handmaids' Tale beautifully shows different ways in which language can manipulate humans' minds and make them behave obediently. Power is not a simple process in which orders are clearly given and in which individuals can always recognize the powerful forces. Sometimes, the power that is everywhere needs to penetrate any aspect of individual life secretly and in a hidden way. One of these hidden ways is through language. By showing the power of language, Margaret Atwood becomes a strict critique of societies in which individuality is undermined.
\end{abstract}

Keywords: language, power, storytelling, confession, social hierarchy. 
The word is a flame burning in a dark glass. (Margaret Atwood The Blind Assassin)

\section{Introduction}

The concept of language and its relation with power seem to be the most mindboggling issues of recent decades. What is language? How does it affect the system of power? Is there anything special about language and its usages? Or is it just considered as a means of communication?

The role of language in forming power as well as overthrowing it is intriguing and debatable. Language, as Foucault believes, is the primary means of power by which individuals have been introduced to society, solidified their positions in society and also spread power's doctrines and ideologies through members of societies (Will to Truth 179). In Margaret Atwood's The Handmaid's Tale, language plays a crucial part in shaping and changing individuals; the power system guarantees its future and its authenticity through language. Although the language is a sign of power and can act as its representative, its role is not always a dominant one, in fact, sometimes it manifests itself as a suppressed and restricted entity. Irrespective of its extended domain, individuals do not have complete access to the realm of language and even they are not permitted to exploit words freely and express themselves thoroughly. Language is no longer an "autonomous construct" (Fairclough vii), a series of "sentences", but rather an "action" (Fairclough vii) which makes the society the proper ground of struggle for power through the production of language as a kind of discourse. As maintained by Linda Thomas in Language, Society, and Power, "language can be said to provide a framework for our thoughts, and that it is very difficult to think outside of that framework" (39), as a result, it is "possible to use language to manufacture an ideology which could steer the way people think" (39); because it would become too difficult for one who desires to think outside that framework; anything a person learns, believes and thinks is in control of language that is an agent of power relations.

The principal purpose of this paper is to consider the role of language in forming the system of power and its subversive role to crash down the system of power, likewise. There are many leading theoreticians who focus on power-language relationships. This paper will concern itself with the theories of three well-known theoreticians whose ideas and opinions on power and language have proven pivotal to any such discussions. First, the theory of Norman Fairclough seems necessary to be discussed because, even though it offers a very "sympathetic" (Rouse 95) analysis of the Foucauldian understanding of power and language, it is, in nature, a more precise focus on the role of language in power system as well as social life. Fairclough introduces the new definition of language and its practicality in forming the system of power. Not only does language have a significant role in communication and in making the daily and ordinary interactions much easier, but also it is a tool in the hands of power. Secondly, it will discuss how feminists employ linguistic theories to talk about the importance of language in power systems. And finally, I will argue that language does not have a fixed entity and nature, and as a result, it causes so many challenges in numerous conditions and situations. Furthermore, new concepts and principles are made or formed on the grounds of these challenges. In fact, the understanding of power structure is "dependent on knowing the language" structure and how language helps its speakers to accomplish their personal and social goals (Fairclough ix). Moreover, language is able to take sides with one ideology and make it the dominant one, and simultaneously make the other suppressed, obedient, or defeated. Finally, I will discuss how a dynamics of power and its volatile features can sometimes have counter-productive effects and, in short, take steps against the dominant power hierarchy.

\section{Definition of Language}

Language, which seems to be the easiest means of communication in daily lives, and has become the focus of many debates of recent times, has been widely studied. Attempting a unique and widespread definition of language seems impossible because the concept of language depends on a variety of factors and it may change in the course of time. Foucault, a distinguished pioneer of showing the indissoluble relationship between discourse and power, is one who offers the new way of defining the language and its usages. Foucault defines language in The Will to Truth as "the means by which an individual is initiated into society"(179). However, people are rarely "free to say anything" (Sheridan 119) and express their real feelings and intentions; there are always social, cultural, and familial barriers that are perennially imposed on each individual. Moreover, "We cannot speak of anything," 
Foucault says, "when and where we like, and that just anyone, in short, cannot speak of just anything" (119). The whole network of language must be supervised. There is no limiting point for language. In fact, the domain of language is infinite, but one cannot experience this infinity, and one always has to be cautious about anything he/she utters. For example, The Handmaid's Tale tells the story of Offred, a woman who used to have a normal life in a country once called America and then fell victim of the political changes that lead her alongside many female characters in the story to lose anything that had and become objectified in a new regime called Gilead. In the beginning, the power system needs to inculcate its principles and doctrines into the members of society, but it should be done in a way that individuals think they are free to choose. The best means by which individuals can be persuaded is language. The power system selects some of them to be its spokesperson, namely Sereba Joy who becomes dominated later by the power system and becomes speechless. She cannot reveal her pent-up emotions, feelings, and suffering since the power system stifles her, like the other women in society.

Some argue that human beings are free to choose their words; however, it should be noted that even chosen words are the direct result of their social and cultural training and the condition in which they are raised. Consequently, human beings are never able to extricate themselves from those mandatory bonds. Society and its culture play a crucial part in the production of discourse. Since the advent of language, people have felt themselves trapped in the network of language. Although language gives them the way to speak and the apparent freedom of speech, people do not think that they are totally free to say whatever they want even in their daily interactions. It is completely shown in The Handmaid's Tale when none of the characters are free to speak even if some belong to the higher rank or they are the power agent; their destiny is the same. Power system tries to suppress them and make them bottle up their real emotions; Serena should tolerate the presence of other women, the Commander should come to terms with his loneliness and lack of communication, and etc. There is a shadow of fear that forces them to be cautious. As a result, it is too difficult to have a thorough definition of language.

\section{Language as a Discourse and Its Relations to the Power System}

Discourse is made by language, and it cannot be considered as an absolute "autonomous structure, simply a system of sentences" (Fairclough vi), rather, any discourse depends on the time and the place in which it is made. On the one hand, social, cultural, political, and individual factors impose their respective limitations on discourse. Consequently, language has always been formed and controlled by the power system; so that language structure can never be far from the act of limitation, censorship, prohibition, and distortion. Discourse, constructed by language, and as a widespread reality gets admiration and "veneration" (Sheridan 126) of many because of facilitating the act of communication. Therefore, people usually overlook their covert capability to impose prohibition and limitation on each individual. On the other hand, firstly, in some situations, the speaker speaks either intentionally on behalf of the other or unintentionally repeats the others' beliefs or opinions. Foucault was "the first to teach us something absolutely fundamental: the indignity of speaking for others [;] We ridiculed representation and said it was finished, but we failed to draw the consequences of this theoretical conversion to appreciate the theoretical fact that only those directly concerned can speak in a practical way on their own behalf" (Foucault The Will to Truth 111-2).

Secondly, language becomes the site of power in order to practice its objectives and to make the linguistic domain constrained by its rules, which frequently measure individuals. Moreover, by means of language, people are able to "articulate the effects of a certain type of power and the reference of a certain type of "discourse, "the machinery by which" policies of the power system can be implemented (Sheridan 138). Thus, language "extends and reinforces the effect of power" (Sheridan 138). It is not important whether "discourse is produced by power" or that power can be "produced by discourse" (Sheridan 168); both have been mutually interwoven into one another so that both of them simultaneously become the object and instrument of the other in an effort to precede their desirable plans. What makes this relationship interesting is that the discourse/power relationship, as Foucault believes, is not predictable and "centralized" (The Will to Truth 168); indeed, it has many occasions in which this relationship produces double meanings which cannot be easily decoded. However, when one wants to disclose 
and decode the hidden meaning of any discourse or language, they will find the fear which had been already there, Foucault says.

Thirdly, it is not true that one should suppose that language has a fixed and continuous entity. There are many factors that have a direct or indirect influence on it, so it must be "treated as discontinuous practices that variously intersect, juxtapose, and exclude one another" (Sheridan 126). Since language is thought to be an influential agent of the power structure, it is neither fixed nor pre-constructed due to the fact that both are at the stake of time and place and so they can undergo the process of change. What is more, the presence of any discourse depends on its political, cultural, and social conditions and it can lead to different types of discourse which might not be stable and fixed entities through the passage of time. Power uses language, on the one hand, to standardize, stabilize, and unify the social condition and people, and on the other hand, to inject its objectives, which seem necessary for creating the delusion of having a fixed entity even if it is not true in reality.

And finally, Foucault states in The Will to Truth that one "must not go from discourse towards some inner core of meaning concealed within it" (126), but that the impact of external elements and conditions in regulating and normalizing any given discourse should be taken into account in order to decipher the hidden meaning of that discourse. Paying attention to the social and cultural atmosphere in which the discourse was born is essential because, as mentioned earlier, discourse is the favourite tool of the power system using which it can dictate and internalize some of its beliefs. Normally, power is "disinterested [in] unveiling of" (The Will to Truth 139) its track on social, cultural, familial, linguistic or even individual matters; nevertheless, by close observation and attention to the centralized discourse, one can find its trace.

\section{External Factors in Discourse}

There are different external and internal factors that not only shape but also control language as one of the most significant signs of power. However, in this section, the external factors and their importance will be discussed.

First, such factors can be divided into two groups of "division and rejection" (Sheridan 120). The exchange of power between them can always jeopardize the dominant system. Foucault says in The Will to Truth that power, through the network of language and its apparatuses, not only controls but also "penetrate[s] individual's right to their most private issues" (168), namely the way of living and even choosing a love partner by using the act of division and rejection. The Gilead society divided people into two groups: male and female; also there are numerous subcategories within these two groups. What is noteworthy about these subcategories is that they all put forth different definitions of language that seem to contradict one another. Although the discourse of the lower levels is not "treated" as an important and effective one, their counter-productive effects can challenge the dominant power because they are "attributed with strange powers of hidden truths" (Sheridan 120). The importance of language in creating the hierarchy should be emphasized. Language becomes the mediator of the power system that intends to "make decisions, to control resources, to control other peoples' behavior and often to control their values" (Linda Thomas 36). And language is the way to guarantee "the acquisition of power and the enforcement" of power and the longterm existence of the hierarchy (Thomas 37).

This hierarchy shows that language cannot be a preconstructed entity that exists before the social situations. As Fairclough has maintained, the language system is like "an army" (Fairlcough 21) that is under the control of power relations. The standardization of both society and people takes place through language. The Atwood's novels, with which this paper is concerned, show that "everyone in a language community" does not have "equal access to" language and that the "command of standard languages are unequal" (Fairclough 21). In fact, by the notion of hierarchy and unequal access of people to the language, power strives to legitimize itself among different groups of people so as to finally enslave them. The possibility of having a real conversation wanes with the creation of such a hierarchy. In The Handmaid's Tale, the Handmaids do not have the permission to communicate with one another loudly and overtly, and if they had a desire to make verbal interactions, it would be hidden.

"We learned to whisper almost without sound" (HT 14).

After this ritual viewing, we continue on our way, heading as usual for some open space we can cross, so we can talk. If you can call it talking, these clipped whispers, projected through the funnels of our white 
wings. It's more like a telegram, a verbal semaphore. Amputated speech (HT 211).

He has something we don't have, he has the word. How we squandered it, once (HT 99).

By omitting the chance of conversation, they are being ignored in an indirect way in both social and political scenes, and they are also deprived of having an "intimate conversation" (Wareing 89); accordingly, they lose both having free access to the linguistic domain and their self-confidence, which has been undermined by language. The verbal language seems dangerous to the Gilead regime because a person may gain the opportunity to renew the situation and simultaneously, challenge the dominant structure. According to Fairclough, "one aspect of power is the capacity to impose and maintain a particular structuring of some domain or other-a particular way of dividing it into parts, of keeping the parts demarcated form each other, and a particular ordering of those parts in terms of hierarchical relations of domination and subordination" (Fairclough 13). Language is believed to be "a form of social practice", as Fairclough says, because "it is a part of society" and it cannot be considered as the external element that stands out of the system (Fairclough 22). It is "a socially conditioned process" that keeps the discourse in order and puts someone in the position of power while the other is subordinated to it; finally, it lets people of higher rank control and reshape the outcome of language (Fairclough 22). In The Handmaid's Tale, the relationship between language and the social hierarchy is proved to be an internal one in which people had been determined socially to use a special language. The way people talk is the direct result of their social training, and it depends exactly on the level to which they belong. Their discourse is strictly controlled by the male discourse of society. Offred tried to depict her society within the framework of discourse, and also criticize the double-standard of social hierarchy in which the system of language is not equally distributed. She thinks that language can be free from those power boundaries. However, in reality, the type of language and the way she uses it show something else; the language as the apparatus of power aims at suppressing women in society.

It is supposed that language is dominating only women of the story, but in fact, there are moments when men are also trapped, limited, and devalued by language.
Language defines for each group "what each is allowed and required to say, not allowed or required to say, within the particular discourse type" (Fairclough 38). In The Handmaid's Tale, playing Scrabble is a symbol of the loss of freedom. Both men and women in the Gilead society are victims of the power system. The lack of communication as well as having limited access to the language system is something they have to tolerate. Even being in the top position of the hierarchy means having lost something, and it is because of this that Serena Joy becomes speechless, and the Commander's burning ambition is to communicate with someone, which leads him to play Scrabble with his Handmaids secretly. To him, it is more exciting than their compulsory sexual relations. This game, on the other hand, brings a sense of freedom for the Handmaids, too. They are not allowed to read and write, and even speak words out of the system. Through this game, Offred is given a new chance to remember what she had already lost. 'The word game' brings her a kind of sense of freedom, and it endows her with the feeling of having power over language. She enjoys it because she is engaged "in public discourse with men" (Butler 67). When The Commander gives her the chance, she starts to use it as his weak point to overthrow the patriarchal language. It shows that not only are the Handmaids forbidden from having verbal interactions with one another but also that the higher ranks also suffer from a kind of verbal harassment.

What had I been expecting, behind that closed door, the first time? Something unspeakable, down on all fours perhaps, perversions, whips, mutilations? At the very least some minor sexual manipulation, some bygone peccadillo now denied him, prohibited by law and punishable by amputation. To be asked to play Scrable, instead, as if we were an old couple, ..., a violation too in its own way (HT 163).

In The Handmaid's Tale, the lower participants of each group, whether they are men or women, are either "compliant" linguistic users or "compliant witness" (Fairclough19) of the power of language. On the other hand, in both The Handmaid's Tale, the women of higher rank are somehow trapped in the language structure. Moreover, it shows that language on the one hand gives freedom to talk and on the other hand limits the freedom of speech of those to whom the privilege has been given. In the case of The Handmaid's Tale, Serena Joy was "an agitator of the values" which would 
later become the rules in Gilead and would trap her in the world of her words (Pettersson15). She was the representative of words; she made speeches in order to persuade the other women to stay at their home and dedicated them to the patriarchal power system.

Her speeches were about the sanctity of the home, about how women should stay home. Serena Joy didn't do this herself, she made speeches instead, but she presented this failure of hers as a sacrifice she was making for the good of all (HT 55).

The aforementioned excerpts indicate the hypocritical aspect of language in manipulating the minds of others, especially those who are not capable of taking any steps against power relations. However, after the creation of Gilead, her power is taken away from her and the recreation of hierarchy devalues her so much so that even if she is still in the position of higher rank, she becomes powerless, too. "Once a discourse type has been settled upon, its conventions apply to all participants, including the powerful ones" (Fairclough 47). Because:

She doesn't make speeches anymore. She has become speechless. She stays in her home, but it does not seem to agree with her. How furious she must be, now that she's been taken at her word (HT 56).

Thus, one could argue that language is an insincere medium of power relations because the power system first manipulates its agents like Serena Joy, and later Aunts to introduce its doctrines to each level of society in accordance with its needs, and then sentences them to be in prison house of their speeches, and through this method, it shatters them and makes them selfless. Therefore, language can be a mask in order to make the trace of power relations in creating the hierarchy invisible, a mask that gives the person the opportunity to hide their real desires, intentions, and purposes.

The role of language in creating social strata is significant. Language shows "the lines of tension" (Fairclough 8) in the power structure that try hard to legitimize people of each group as the representative of either the dominant power or subordinated to the power structure through the production of language. It shows the lack of stability and coherence in the linguistic structure as well as the power structure. Making those categories helps participants of each level to raise their awareness about how language plays an active role in the domination of some people by the other; it is through this "consciousness" that the subordinated can take steps toward "emancipation" (Fairclough 1). According to Fairclough, the effectiveness of the power of language always depends on "power of their users", who uses it and when? (Fairclough 1) In fact, the graphs illustrate that the way people interact with each other depends on the social group to which they belong. Because the way language defines their roles and their limitations are linked to their social level. Thus, each wishes to know to what extent their position allows them to participate in the production of language and in the power system; if they are not allowed to participate in such practices, the only remaining alternative is to be a "fully compliant" individual (Fairclough 19).

In showing language as an action, these graphs are very important because:

First, the act of division makes the possibility of having a real conversation and interaction illusory.

Second, language illustrates that the variation is "not a product of individual choice, but a product of social differentiation" (Fairclough 21) whose purposes, social setting, and future prospects are stabilized by the dominant language.

Third, the emergence of different ideologies stems from the possibility of having struggles within the linguistic structures of each group, struggles that finally lead to the domination of the ideology which is in accordance with the framework of the dominant power structure. Logically, "the maximization of the profits and power of one class depends upon how language internalizes their favorite codes" (Fairclough 34-5). Language defines the codes of each group and determines what one is allowed to say and what one is not allowed to say in particular or even ordinary interactions, as Fairclough believes.

\section{The Role of Ideology in The Handmaid's Tale}

Ideology is the outcome of power relations as well as power struggles. When people interact linguistically, they are not often consciously aware of the role of ideology that has internalized their favorite codes. An example would be how the Gilead conventions penetrated into each individual mind in a way that they 
forget their prior norms of society or the way they prefer not to remember them.

At Red Center, Aunts have a great responsibility to teach and codify the given doctrine. Thus, a relationship between the Aunts and the Handmaids embodies a "common sense" assumption that shows hierarchy as a natural process (Fairclough 2). The Aunts know about the way of salvation and the method of holy life whereas the Handmaids don't. The Aunts are in a position to determine how a woman should behave, and how she should be treated in this system; they also know what the main role of women is, and the Handmaids are the ones who need to be informed linguistically. As a result, "the ideologies are closely linked to power" and in this relationship, the presence of language is highly necessary because "ideologies are also closely linked to language, because using language is the commonest form of social behavior" (Fairclough 2 ). The language provides the proper ground for ideologies to reveal themselves, and therefore language is important enough to gain the attention of ideologies that are the "means of legitimizing existing social relations and differences of power" (Fairclough 2). In The Handmaid's Tale, there are different types of ideologies, the ideology of the dominant group, and the ideology of lower ranks. Since there is a contradiction between them, the power system needs a place to guarantee the permanence of its doctrines. The Red Center is the place where language appears in its commonest forms to dictate and internalize the ideology of the power system, due to the fact that the exercise of power in each society is mostly achieved through ideology. The Aunts try to naturalize these accepted ideologies in the Handmaids; they know naturalization is "the most formidable weapon in the armoury of power and therefore a significant focus of struggle" (Fairclough 105-6). The ideology is a guarantee to keep the authority hidden behind discourse, because ideology deals with minds, so its effects cannot be easily seen in the physical world, and as a result, the addressees assume that they are free in the linguistic domain. The ideologies make the Handmaids terrified to take any steps against the power's will. Offred cannot act against the law even if she knows the law is inequitable. "Wittig believes the power of language to subordinate and exclude women; language is an institution that can be radically transformed" (Butler 35). To substantiate this, Offred is always terrified in her daily conversation to choose a word to talk or answer because she thinks that words can cost her a lot. This can prove how the language system can limit the freedom of individuals. She is not free to say whatever she wants and whenever she desires. Besides, if the power of language is accepted to be the main factor in "social stratification" (Jones 143), the controversial question, i.e. who "gives order" and who "takes it" and based on what factors this linguistic authority is given, emerges (Jones 147). To answer this question means proving Fairclough's theories of the power in discourse and the power behind it.

Repetition and memorizing are the tools of Ideology. The Aunts, who act as the authorized handlers of Gilead Regime, prepare Handmaids and subject them to the system through the ideology. As it was mentioned earlier, the system tends to group people; also, one of the ideology's tasks is to divide people and impose certain roles upon them, an act that usually happens by repetition. The Handmaids are believed to be a fallen, outcast, and dried entity if they are not acting in accordance with the system. Nevertheless, if they are good performers, they will be transformed and completed.

Aunt Lydia: they also serve who only stand and wait. She made us memorize it. She also said, Not all of you will make it through. Some of you will fall on dry ground or thorns. Some of you are shallow-rooted...Think of yourselves as seeds....Let's pretend we're trees (HT 28).

Another belief the Aunts try to naturalize is that women must be invisible in society. "Aunts Lydia said Never Forget it. To be seen-to be seen- is to be...penetrated. What you must be girls, is impenetrable" (HT 39). The most important manifestation of this doctrine is when the tourist group wants to take a picture, and Offred says no because she is so drown to the ideological doctrines of Gilead society. What is noteworthy is that Offred, regardless of her previous freedom and visibility in society before the creation of Gilead regime, is so intoxicated by the ideological discourse, introduced by the Aunts, that she cannot think differently now.

The interpreted turns back to the group, chatters at them in staccato. I know what he'll be saying, I know the line. He'll be telling them that women here have different customs, that to stare at them through the lens of a camera is, for them, an experience of violation (HT 39). 
The Handmaids are banned to talk to the other men and must be seen inaccessible. The women in society should be speechless and silent in their verbal confrontation. They are thought to be vulnerable to temptation and should be reminded to be careful.

Nick looks up and begins to whistle. Then he says, "Nice walk?"

I nod, but do not answer with my voice. He is not supposed to speak to me. Of course some of them will try, Said Aunt Lydia. All flesh is weak. All flesh is grass,...They cannot help it, she said. God made them that way but He did not make you that way. He made you different. It's up to you to set the boundaries. Later you will be thanked (HT 55).

In fact, verbal discourse plays a crucial role in "locating individuals" (Rouse 98). The ideological norms are not only made linguistically but also become common in each social relation. The Red Center and the Aunts are in charge of setting certain behavioral codes and defining the Handmaids' roles. Power is born among the astute plays of words and the way they are presented in society. The handlers in the Red Center managed to turn women against themselves and their own beliefs. The Handmaids become puppets, and they masquerade their real selves, or even worse, they forget their reality. Language, in corporation with ideology, changes the way they behave and they dress; consequently, a new self is born, and it substitutes the old one that cannot be called authentic. The dominant ideology wipes out and destroys the old selves and simultaneously makes them seem as heresy. "We are fascinated, but also repelled. It has taken so little time to change our minds" (HT 38). The Gilead society acts as a symbol of sovereignty. In The Handmaid's Tale, the hierarchy attempts to be the symbol of law and order, but in Offred's opinion, it cannot be the symbol of justice even if it claims to protect women in society. Against Foucault's theory, the society cannot solve the hidden conflicts among different layers of the hierarchy or even the same level in a seemingly "unified and coherent system" (Rouse 103) although the Red Center tries vainly to destroy the possibility for its inhabitants to have second thoughts. The Red Center prioritizes the collective belief over the individual one. If a person protests, they will be punished in different ways. The system is not the "protector of peace" (Rouse 103) caused by language, it is more a cause for chaos inside the system. Language tames human beings, especially women, in order to "disseminate" the doctrines of power through "more extensive social network" (Rouse 105).

The only possible way to knock down the coherence in social stigma is language. The characters tried to use the power of words to gain power and challenge the current ideology. It is believed that language cannot sit on the fence and act neutrally, rather, it is always trapped in the power system, and it is the "product of the ideologies" (Jones and Peccei 38). Therefore, it is an important task assigned to language to provide a valid framework of thought and make sure everyone cannot think and act linguistically outside of the given framework. Language, on the one hand, "manufactures an ideology which could steer the way people think" (Jones and Peccei 39) and on the other hand, it provides the resistance force to smash it down. Language can be used not only to steer people's thoughts and beliefs but also to control them.

Offred's thought is so surrounded by the linguistic codes of how to behave she cannot think outside the box. However, she still remembers the codes of her past life: she is not brave enough to take any dramatic action to change the situation. The ideological system attempts to impose certain ways of speaking and using language upon all participants of each group. Its purpose is not only to use language as the "medium of expression" (Jones and Peccei 39) and mental habits proper to "the power system, but to make all other modes of thought" and speaking "impossible" in a way that "they determine their perceptions of the word" (39). The Gilead society wants to inspire each level of society by a special thought that makes them useful for the system. The Wives should be patient enough to share their husbands with the Handmaids, whereas the Handmaids should sacrifice their self for the sake of the future generation. At the Red Center, the prior thoughts of the Handmaids which somehow were the prerequisite of their validity have faded away or stored in an unconscious mind. Therefore, they are not able to exert considerable influence within the linguistic structure of society. The language introduces the new doctrine in order to make them aware of their roles. On the one hand, language must be appreciated to form the thought, and on the other hand, language makes the possibility of having the same meaning for everyone farfetched. The Scrabble game is the breaking point of the dominant language because it gives permission to the deprived minds to have access to forbidden words. 
It could be argued that Atwood shows the failure of the hierarchal society. Foucault believes that "power is everywhere not because it embraces everything, but because it comes from everywhere; power is not possessed by a dominant agent's, nor located in that agents relations to those dominated, but is instead distributed throughout complex social networks" (Rouse 109). They act to establish the connections between "what a dominant agent does and the fulfillment or frustration of a subordinated agent's desires" (Rouse 109). It must happen through the ideological surveillance of its members. The commander's wife, Serena Joy, is a kind of female authority, but it is just on the surface; in reality, she was dominated by the power system when there was no need for her services in the public scene. Thus, within the hierarchy, women are often envious of one another instead of being supportive, and it is against the will of power and the Aunts' training. Aunts attempted to reconcile women with one another in order to carry each others' responsibility, but they fail. "What we are aiming for, says Aunt Lydia, is a spirit of camaraderie among women. We must all pull together" (HT 234). The Commanders' wives resented the Handmaids for breaking into their private room and stealing away the attention of their husbands; the Handmaids resented the wives for participating in sexual intercourse; Marthas resented both the wives because of imposing their responsibilities on the Handmaids, and the Handmaids because of devaluing themselves. The Aunts want them to be unified, but they become an enemy of each other and somehow an intruder. The Aunts want to persuade them through the verbal language, that they should be the "transitional generation" (HT 127) and pass on Gilead ideologies. Nevertheless, they fail to make them act as a catalyst.

For the generations that come after, Aunt Lydia said, it will be so much better. The women will live in harmony together, all in one family; you will be like daughters to them... There can be bonds of real affection... Women united for a common end! (HT 170)

You are a transitional generation, said Aunt Lydia. It is the hardest for you. We know the sacrifices you are being expected to make. It is hard when men revile you. For the ones who come after you, it will be easier. They will accept their duties with willing hearts.

She did not say: Because they will have no memories of any other way.
She said: Because they won't want things they can't have (HT 127).

It somehow happens when, later, Offred explains the marriage ceremony between Angels and young girls, who they were prevented from seeing any men and having any relationships. However, Offred believes that the new generation will question this way of life, and they cannot be enslaved forever. Moreover, two of the problems are, firstly, the linguistic system of power, and ideology that try to "cast all women as powerless victims" regardless of the group they are in, and "cast men as undermining, excluding, and demeaning women" (Wareing 90). Therefore, as a result of this inequality, women try to penetrate the system. Although Serena Joy becomes silent and cannot make speeches anymore, she tries to break the law by sending Offred to Nick. The Aunts are not powerful, indeed, although they think they are. They act as the mask of power, and they have an active role in reshaping the subjects. The subjects are people who were raised by different types of ideologies. Some take steps against any new ideological discourse, namely Moira, and Laura or even any discourse whose aim is to destroy them. And some become blind-followers of the system, such as Offred and Iris. However, there is always a chance to be a rebellion; that's why the Gilead society fails to create a "coalition action" at the end (Butler 27).

\section{Internal Factors in Discourse}

One of the ambiguities of language is in some situations where there is a contradiction between what one says and what one means. The Handmaids are supposed to judge each other verbally and give their opinions loudly however untrue it may seem. They cannot freely express what they think. On the one hand, they have already been indoctrinated and their judgment is not neutral, and on the other hand, there are always the watchful Aunts who check the words out of their mouth, and if their speech is not legitimized by the power system, they will be severely punished. Thus, whatever the Handmaids pass as a comment, it is not against the system. All of them have to have the same comment; the Aunts make them appreciate the collective commentary over their personal ones. The power system functions through the Aunts and internalizes some ideologies so as to make everyone reach the same way of thinking and conduct. This is because following this way; they can guarantee their future existence. The system stole away something much more valuable than 
what the Handmaids think, and that something is their thoughts. They become automatons of power, and painfully, they get used to not thinking so much. "I try not to think too much. Like other things now, thought must be rationed. There's a lot that doesn't bear thinking about. Thinking can hurt your chances, and I intend to last" (HT 17). It seems that they can survive if they are silent followers of the dominant thought who do not dare comment on anything against society.

Aunt Helena is here, as well as Aunt Lydia, because Testifying is special. It's Janine, telling about how she was gang-raped at fourteen and had an abortion... All Testifying, it's safer to make things up than to say you have nothing to reveal... But whose fault was it? Aunt Helena Says.

Her Fault, her fault, her fault, we chant in unison. Who led them on? Aunt Helena beams, pleased with us. She did. She did. She did... (HT 81-2)

The painful revelation is not only that the other Handmaids believe or pretend to believe that she was guilty, but also that after having some confessional sessions in a row, Janine found herself guilty, too. "Janine doesn't wait for us to jeer at her. It was my fault, she says. It was my own fault. I led them on. I deserved the pain" (HT 82). Fairclough believes that whenever people interpret discourse and comment on different issues, they necessarily obey the law of hierarchy and based on the order of discourse, the commentary language is produced (Fairclough 39). So, language constantly reproduces itself, and as a result, it increases the chance of its survival. The more natural "the functioning of an ideological assumption in the construction of coherent interpretations, the less likely it is to become a focus of conscious awareness" (Fairclough 85) and hence the more secure the power system is. In The Handmaid's Tale, there are two kinds of commentary: first, the commentary that is given by the Aunts in order to show how the Handmaids must think. The second type of commentary belongs to "discourse participants" (Fairclough 141) which are done by the Handmaids. It is clear that this kind of interpretation is based on what they learned at the Red Center and what the system lets them. The less contradictory relationship there is between these two types, the more powerful the system will be. These types of commentary aim at "typifying the ways in which specific classes of subject behave in social activities, and how a member of special classes of subjects behave towards each other-how they conduct relationships" (Fairclough 159). The Aunts' exertions had left the Handmaids feeling enslaved by the linguistic structure due to the fact that they could not express their opinions, their concerns about confessional sessions and confessors freely. Thus, being good in the eyes of society happens when their stereotypical role is internalized in their minds. The commentary has a longterm effect on the interpreters. Therefore, considering the social and political situations which give permission to language to function as a power apparatus is always important. Since time and place are not stable entities, the members of the society who are the true users of language are also changeable; these two conditions make language itself an unstable entity. The more identical the commentary of the Handmaids, the more impenetrable the power will be. When there is a possibility of diversity, power always attempts to impose its own interpretation upon the non-powerful interpreters, such as the Handmaids in Atwood's novel. One could presume that although the system tried so hard to equalize the outcome of the commentary, there is always an unintended reproduction of the discourse that acts against the rules. The objective of the stage of commentary is "to portray a discourse as a part of social process, as a social practice, showing how it is determined by social structures, and what reproductive effects discourses can cumulatively have on the structures, sustaining them or changing them" (Fairclough 163). Interpretation is a mental process that is invisible and inaccessible for both the listeners and the interpreters, so something is needed to bring it out to the physical world, and language seems to be the best candidate. The Gilead regime is criticized by Offred. This criticism somehow stems from the power system itself. It is believed that the system always prohibits, limits, and censors language; however, it is the system that, unintentionally, paves the ground for the possibility of having resistant forces in the form of language. This resistance against the power of Gilead starts with the confessional sessions in which the Handmaids have to comment on others and label them. Offred says that we have to fabricate something like a confession even if there is not anything to confess. Otherwise, we get punished. The system hurts itself because when the power of imagination is activated, the participants will have access to the prohibited realm of language. The last step that leads Offred to free herself and make sure of the power of words is Scrabble that activates her mind. In her imagination, she plays with 
words, she makes love, and she takes revenge. At the end of the story, before she becomes the passenger of an unknown future, she has killed the Commander verbally even if in reality she couldn't. The Handmaids are dominated by confession since their narratives are structured around the efforts of the representatives of State power-The Red Center-to extract a confession from them. How could one confess "seriously of a subject that aroused only disgust or ridicule? And how could one tell the complete truth about their sin and" avoid both hypocrisy and scandal? (Sheridan 169) The urgency to confess is imposed on them from outside, and they have to share the most intimate details of their lives which are not easy to verbalize at all. Consequently, they do not share the truth. The Handmaids make themselves vulnerable by exposing their innermost thoughts, secrets, and desires. And it is completely natural for them to avoid telling the truth and to gloss over some facts by manipulating the words.

Finally, the Aunts take the Testimony too seriously because its aim is "to maximize output" of the regime and "to reduce the incidents, interruptions, disturbances, and the formation of secret associations" (Sheridan 149). And the examples of their failure would be Moira, and Mayday as the underground secret organization.

\section{In The Handmaid's Tale, Storytelling is a Faint Hope in a Dead Language}

Speaking is an integral part of all kinds of human relations. In The Handmaid's tale, the act of storytelling functions as a shout in order to have a listener or to find someone to whom one can talk. By creating imaginary audiences, Offred finds a way to give away all her bottled-up emotions, traumatic experiences, and on top of that, a way to confess. In the Gilead regime, the Handmaids are deprived of verbal communication, and as a result, she chooses storytelling as the ultimate substitute. "Feminists are particularly interested in stories because as a marginal group of society, women have often been the objects rather than creators of narratives: their stories have often been untold", as Karen Fostein has said (Pettersson 6). Offred, who was the marginalized person and who was not taken seriously in the Gilead society as a person who can give an opinion and talk about serious issues, is sick and tired of being silent, and she decides to tell her life story, whether as the steps taken against the domination or just narrating the injustice of her society. Since "all social systems are vulnerable at their margins and that all margins are accordingly considered dangerous" (Butler 168), it is not an easy decision at all to unfold some prohibited words in order to let the words fight against the power system. The fight between the forces of power, i.e. the dominant power and the subordinated power, starts when Offred shares her memories of life in the Gilead society. This fight is dependent on language. There is a relationship between power and language, but this very language in each society is controlled, monitored, and shaped by power relations. So what one says or what one does not say, what is accepted or what is unaccepted have already been defined. Offred chooses the oral form for telling her story over the written form, because, firstly, writing had been prohibited by the regime. Secondly, handwriting can lead the authorities to find her. Thirdly, she desired to talk to someone even if there was an imaginary one; and finally, the act of storytelling was a way to mitigate her pain. She was hurt in the Gilead society, and in telling her story, she could imagine herself as a patient of a psychoanalyst who invites her to talk.

Tell rather than write, because I have nothing to write with and writing is any case forbidden. But if it's a story, ever in my head, I must be telling it to someone. You don't tell a story only to yourself. There's always someone else. Even when there is no one (HT 149).

Offred chose the spoken text as a way of sharing her life story because it seems more descriptive than reproducing something which people can refer to as a valid document. Also, another reason is that "it is men who have driven away women from writing in order to defend the patriarchal order" (Davis 59) of discourse. However, it does not make any difference she chooses which way to narrate her life story, oral form or the written one. Both cannot fully portray the society and cannot heavily criticize it because of being in control of the power structure. I think the kind of language she uses is to a great extent the one practiced and approved in Gilead; "it is a language that is male dominated, and Offred can be seen to exist within a male discourse, which limits her position in the society of Gilead; hence, Offred's narrative is, although written in a place outside Gilead's discursive reach, not free from the frames of what Gilead discourse allows her to think" and say (Pettersson 6).

When I get out of here, if I'm ever able to set this down, 
in any form, even in the form of one voice to another, it will be a reconstruction then too, at yet another remove. It's impossible to say a thing exactly the way it was, because what you say can never be exact, you always have to leave something out, there are too many parts, sides, crosscurrents, ... which can never be fully described... (HT 114)

It cannot be said that the reconstruction of language through the act of storytelling does not take any steps against the dominant power. The violence of storytelling as a kind of discourse targets the illusionary unified structure of the language system and makes it seem as "a lifeless construct" (Butler 161) which has not had any power against Offred's story. Offred is speaking on behalf of herself, her listeners, and indeed all. The storytelling authorizes Offred as a preacher who imposes the act of listening to everyone and coincidentally gives scathing remarks about her society, and then challenges the whole power structure. However, there is some evidence in the story that proves that Offred, indeed, does not want to find an "alternative" (Rouse 115) for the Gilead regime; her aim is to identify and introduce the hazardous aspects of her society as well as its weak points. In no way does she want to change society because she does not dare to act publicly; moreover, she does not have any practical model in her mind to make life better. She had been dependent on a male discourse before Gilead, but the form of dependency was different. The world she chose to live in both societies, before and after Gilead, was impressed and surrounded by the patriarchal language and the female discourse was in the margins. Offred's story provides an opportunity for both she and the readers to comment on and be critical of the Gilead regime and indirectly of the patriarchal discourse. Although some may think she finally decides to fight against this gloomy society, she is always afraid of the consequences. Thus, she cannot be entitled as the determined, courageous person whose purpose is to help overthrow the regime. On the contrary, some believe that not only does her narrative reveal a lot of her painful experiences as the Handmaid in Gilead in an ironic tone, it is also an "item of exchange" (Butler 66) to reverse the power's hierarchy at the end. Her story cracks the coherence of the "public discourse" (Butler $66)$. The readers have witnessed that her story gradually defeats the system. At the end of the story, before Offred started her travelling towards an unknown future, The Commander was worried about whatever she could spy on him and tell the others. It is not important whether she reached the destination where she thought she could feel freedom or not, but her message is passed on to the readers, and it introduces her story as the dominant power. It seems that her narrative depicts women in captivity of the male discourse, but it, in fact, "presents men and women as political prisoners" of the Gilead regime, "trapped as victor/victim in their own reflection of the world and of each other" (Somacarrera 45) that has been verbalized. The concept of storytelling evokes the fact that men and women are not free individuals, but they are political instruments. In The Handmaid's Tale, Atwood presumably seeks to overthrow the victor/victim status. At the end of the novel, the female character apparently takes the title of the victor because she chose a good way, i.e. storytelling, to fight. Women, as the minor group, are supposed to be always the victim of the patriarchal language, yet the men, like The Commander, are also suffering from the lack of communication and from not sharing their stories. By Offred's narrative, the power system was reversed because Offred, who belongs to the marginalized group of people, manipulates the others' minds in order to change their perspectives and standpoints about her and her society. She grabs the power and makes all trapped in her linguistic structure and therefore not only does she take revenge for her long-term defeat in Gilead, but also by not letting the readers or the listeners think out of her depicted framework, she compensates those torturous years of living in the Red Center. Also, nobody "sets out to speak" for the Handmaids, but storytelling makes it possible for Offred as one of those doomed Handmaids to "speak about what was happening" in Gilead (Sheridan 128). Although her narrative is not reliable enough because of being dependent on the linguistic framework of the Gilead discourse as well as the society before Gilead, it can be a good strategy to question the validity of her society. However, I think her story cannot make her powerful and brave due to the fact that she never intends to leak information to the outside world; her storytelling is a replacement for real communication to her, but against all odds, it makes the system vulnerable and appoints Offred in charge. She wants neither to replace the dominant discourse with a personal one "nor to establish this very personal discourse as a rival culturally" established language, but rather to validate her personal experiences and painful memories within the Gilead society (Butler 108). 
What I have been saying, and to whom, and which one of his enemies has found out? Possibly he will be a security risk, now. I am above him, looking down; he is shrinking. There have already been purges among them, there will be more (HT 306).

As previously mentioned, language cannot be free from the limited boundaries, but the act of storytelling is a kind of defensive discourse which produces a new set of desires and drives that can have unconscious or unintentional "aims prior to their emergence in to a language" (Butler 103); and the said raconteur employs the aspect of language which has already "repressed or sublimated those desires: (Butler 103) to disobey and free itself of the presupposed linguistic structure. As can be seen, those desires originate in language and end in language. However, what kind of story is made or what effects it has is unpredictable in the linguistic domain on which those desires were firstly formed and then "broke apart the usual" (Butler 104), accepted form of language by producing the likelihood of "multiple meanings" (104).

Finally, the act of storytelling is "described as destroying or eroding" (Butler 105) the language system as well as being productive. It is productive because her narrative "rests upon a severance" (Butler 105) of its relationship with the dominant discourse which leads the hearers of her story to have a new understanding of the Gilead society. On the other hand, it is destructive because its hidden power can challenge any ideology according to which the society had been constructed. One may agree that the act of storytelling gives the readers access to some hidden truth and desires which had been repressed by language and more precisely, by power relations; nevertheless, this access must be decoded or interpreted by the language system. Offred is not able to pass the linguistic boundaries and be creative. How can one interpret the life story of someone regardless of the structure of the dominant discourse? Consequently, her narrative seems not to have any prior desire to rupture the accepted form of discourse, but it is told to mitigate her and to remove the remnants of those traumatic burdens. Storytelling can have a healing role for all the hearers of her story as well as her because her story is a kind of speech in a "dead language" (Butler 176) and this dead language gives people hope to continue and survive. One could argue that apart from its critical view, its first and foremost goal is to survive. It is more a "strategy of survival within the compulsory system" even if it has "punitive consequences" (Butler 178). Those who cannot naturalize themselves are doomed to be outcast, their relations have been soured and they suffer mentally.

\section{Conclusion}

The role of language "has proved to be the most dominant and the most all pervasive; yet, for that very reason, it is the least apparent, the least discussed" (Sheridan122), as if it is a completely free apparatus which has never been influenced, and as a result, it cannot be subordinated. However, the truth lies elsewhere. This very dominant and powerful apparatus is itself subordinated and controlled by power. "Under cover of language", some fundamental and sweeping generalization or naturalization may happen, and it is through the language that one can control and dominate the other and at the same time be qualified to become expurgated (Sheridan 169). Thus, at the heart of this limitation and censorship, something unexpected happens, and the rebellious language pops up to provoke people to rethink the priorities which language had already dictated to us. 


\section{References}

Atwood, M.(1986) The Handmaid's Tale.London: Vintage.

Butler, J. (1999) Gender Trouble: Feminism and the Subversion of Identity. New York \& London: Routledge.

Fairclough, N. (1989) Language and Power. New York: Longman.

Focault, M. (2005) The will to Truth.Ed. Alan, Sheridan. London and New York: Routledge.

Godin D. M., Tilley, H. and Prakash, G. (2010) Utopia/Dystopia: Conditions of Historical Possibility. Princeton, N.J.: Princeton University Press. Web:

http://press.princeton.edu/chapters/i9188.pdf. 2014-12-02

Jones, J. (2004) "Language and Class."Language, Society and Power.Eds. Ishtla Singh and Jean Stilwell Peccei. London \& New York: Routledge. 133-156

Jones, J and Peccei, J. S. (2004) "Language and Politics."Language, Society and Power.Eds. Ishtla Singh and Jean Stilwell Peccei. London \& New York: Routledge. 35-74

Ketterer, D. (2014-12-01) "Margaret Atwood: The Handmaid's Tale: a Contextual Dystopia."Science Fiction Studies.Vol.16. No. 2 (July 1989). www.jstor.org/stable/4239936. p. 209-2017.

Pettersson, F. "Discourse and Oppression in Margaret Atwood's The Handmaids Tale."Linnaeus University, School of Languages and Literature/English.

Inu.diva-portal.org/smash/get/diva2:321781/FULLTEXT01.pdf. Web

Somacarrea, P. (2006) "Power Politics: power and identity. "The Cambridge Companion to Margaret Atwood.Ed. Coral Ann Howells. New York: Cambridge University Press. 43-57.

Rouse, J. (2005) "Power and Knowledge."The Cambridge Companion to Foucault.Ed.Gary Gutting. New York: Cambridge University Press.

Sheridan, Al. Ed. (2005) Michel Foucault: The Will to Truth. London \& New York: Routledge. 
